\title{
The earliest collection of an elusive alien? Evidence of early introduction of Chenopodium ficifolium (Chenopodiaceae) in New Zealand
}

\author{
Sergei L. MOSYAKIN ${ }^{1}$, Peter J. de LANGE ${ }^{2}$ \\ ${ }^{1}$ M.G. Kholodny Institute of Botany, National Academy of Sciences of Ukraine \\ 2 Tereshchenkivska Street, Kyiv 01004, Ukraine \\ s_mosyakin@hotmail.com \\ ${ }^{2}$ Environment and Animal Sciences, Unitec Institute of Technology \\ Private Bag 92025, Victoria Street West, Auckland 1142, New Zealand \\ pdelange@unitec.ac.nz
}

Mosyakin S.L., de Lange P.J. 2020. The earliest collection of an elusive alien? Evidence of early introduction of Chenopodium ficifolium (Chenopodiaceae) in New Zealand. Ukrainian Botanical Journal, 77(2): 81-89.

Abstract. Historical records and the current status of Chenopodium ficifolium (Chenopodiaceae) in New Zealand are considered. This species of Eurasian origin was and still is occasionally reported in New Zealand as a casual alien since its supposedly first record by Kirk in 1896, who found the species in 1892 in the port of Wellington on a ballast heap. At least seven reliable collections / records are known from locations ranging from the North Island (Auckland and Wellington) to the South Island (Christchurch), and one of the southern Titi Islands. However, the actual distribution of the species in New Zealand is probably underestimated because of its similarity to C. album. Probably C. ficifolium was initially introduced to New Zealand much earlier than 1892, as evidenced by the herbarium specimen collected by J. Everard Home in the 1840s. That specimen was recently found in the Turczaninow historical herbarium at the National Herbarium of Ukraine $(\mathrm{KW})$; it is one of many other historical specimens at KW that were collected in New Zealand by Home, A. Cunningham and R. Cunningham in the first half of the $19^{\text {th }}$ century. Most probably, Turczaninow received these New Zealand specimens from the Royal Botanic Gardens Kew in exchange for his Siberian or other collections. We expect that a thorough revision of New Zealand specimens in the Turczaninow herbarium at KW may bring important and interesting results not only on native plants (including type specimens), but also for non-native species introduced during the early stages of the European colonization, which will document their earliest stages of expansion in New Zealand.

Keywords: alien species, Eurasia, Chenopodiaceae, Chenopodium ficifolium, herbarium, history of botany, New Zealand

Submitted 21 February 2020. Published 29 April 2020

Мосякін С.Л. ${ }^{1}$, де Ланге П.Дж. ${ }^{2}$ 2020. Перша знахідка непоміченого чужинця? Свідчення раннього занесення Chenopodium ficifolium (Chenopodiaceae) до Нової Зеландії. Украӥнський ботанічний журнал, 77(2): 81-89.

${ }^{1}$ Інститут ботаніки ім. М.Г. Холодного НАН України

вул. Терещенківська 2, Київ 01004, Україна

${ }^{2}$ Технологічний інститут УніТек

П/скр. 92025, вул. Вікторії (Захід), Окленд 1142, Нова Зеландія

Реферат. Розглядаються історичні відомості щодо трапляння Chenopodium ficifolium (Chenopodiaceae) та сучасний статус виду в Новій Зеландії. Цей вид євразійського походження наводився для Нової Зеландії як випадково занесений адвентивний вид, принаймні з часів першої вказівки Кирка 1896 року, який знайшов C. ficifolium у1892 році в порту м. Веллінгтон на купах корабельного баласту. Відомо щонайменше сім надійних зборів або вказівок у різних географічних регіонах - від Північного острова (Окленд і Веллінгтон) до Південного (Крайстчерч) та одного з південних островів Тіті. Проте, фактичне поширення виду в Новій Зеландії, ймовірно, виявлене недостатньо через його подібність до C. album. Вірогідно що, C. ficifolium був уперше занесений до Нової Зеландії значно раніше, ніж у 1892 році, про що свідчить гербарний зразок, зібраний Дж. Еверардом Хоумом у 1840-х роках. Цей зразок нещодавно був знайдений в історичному гербарії Турчанінова (складова частина Національного гербарію України - KW); це лише один із багатьох ранніх зразків у КW, зібраних Хоумом, А. Каннінгемом і Р. Каннінгемом у Новій Зеландії в першій половині ХІХ століття. Швидше за все, Турчанінов отримав ці новозеландські зразки з Королівського ботанічного саду К'ю в обмін на свої сибірські чи інші колекції. Ми сподіваємося, що ретельний перегляд новозеландських зразків, наявних у гербарії Турчанінова в КW, виявить важливі та цікаві результати не лише щодо аборигенних рослин (включаючи типові зразки), але й щодо адвентивних (чужорідних) видів, занесених на ранніх етапах європейської колонізації; це дозволить прояснити найдавніші етапи їхньої експансії в Новій Зеландії.

Ключові слова: Chenopodiaceae, Chenopodium ficifolium, адвентивний вид, Азія, гербарій, історія ботаніки, Нова Зеландія

(C) 2020 S.L. Mosyakin, P.J. de Lange. Published by the M.G. Kholodny Institute of Botany, NAS of Ukraine. This is an open access article under the terms of the Creative Commons Attribution License (http://creativecommons.org/licenses/by/4.0/), which permits use, distribution, and reproduction in any medium, provided the original work is properly cited 


\section{Introduction}

Chenopodium ficifolium Sm. (Chenopodiaceae, or Amaranthaceae sensu APG) is a species of the genus Chenopodium L. in the strict sense, meaning the group that resulted from the recent segregation of Dysphania R.Br. (see Mosyakin, Clemants, 2002, 2008; Clemants, Mosyakin, 2003; Fuentes et al., 2012b) and several other now recognized genera, such as Blitum L., Chenopodiastrum S.Fuentes, Uotila \& Borsch, Lipandra Moq., Oxybasis Kar. \& Kir., Teloxys Moq. (Fuentes et al., $2012 a, b)$. This generic rearrangement is now widely accepted (see an overview in: Hernández-Ledesma et al., 2015, etc.). However, alternative views on generic delimitation in the group also exist. For example, Feodorova $(2014,2018)$ advocated a much wider circumscription of Blitum, including Lipandra, Oxybasis, and Chenopodiastrum. Zhu and Zhang (2016) and Zhu and Sanderson (2017) recognized additional segregate genera Roubieva Moq. and Neobotrydium Moldenke; however, it is not justified from both phylogenetic and morphological viewpoints (see comments in Sukhorukov et al., 2016a, 2019) because both Roubieva and Neobotrydium are phylogenetically deeply nested in Dysphania. The new genus Carocarpidium S.C.Sand. \& G.L.Chu proposed by Zhu and Sanderson (2017) for C. californicum (S.Watson) S.C.Sand. \& G.L.Chu (that species was originally described and is now properly accepted as Blitum californicum S. Watson, earlier it was also known as Chenopodium californicum (S.Watson) S.Watson) should also better remain in Blitum.

Within Chenopodium sensu stricto, C. ficifolium is an important species from taxonomic and evolutionary perspectives because it is a diploid $(2 n=18)$ representing one of the primary evolutionary lineages, either the extended B-genome group of diploids (also containing C. suecicum Murr and some other less known species) or a close sister group to the core clade of B-genome diploids. Such diploids through hybridization and allopolyploidy gave rise to several other groups and taxa of derived tetraploids and hexaploids (Walsh et al., 2015; Mandák et al., 2018, and references therein). The names C. serotinum $\mathrm{L}$. and $C$. viride $\mathrm{L}$. were partly misapplied to C. ficifolium (see details in: Aellen, 1941; Uotila, 1979; Mosyakin, Iamonico, 2018).

Chenopodium ficifolium is widespread in temperate to subtropical regions of Eurasia, from Atlantic Europe in the west through southern Asia to the East Asian region (Aellen, 1929, 1960-1961; Uotila, 1997, 2001a, b; Paul, 2012; Mosyakin, 2016; Clemants, 2006; Sukhorukov et al., 2016b, 2019; etc.). The species is also known as occasionally introduced in many other regions of the world, such as North America (Clemants, Mosyakin, 2003; Mosyakin, 2016, and references therein), Australia (Wilson, 1984; mentioned as not confirmed), and New Zealand (Kirk, 1896; Allan, 1940; Sykes, 1982; Webb et al., 1988, reported as casual). The highest morphological and probably also genetic diversity of $C$. ficifolium s. 1 . is concentrated in southern (Indian subcontinent) and southeastern Asia, where several infraspecific taxa are recognized, in particular, C. ficifolium subsp. blomianum (Aellen) Aellen (C. blomianum Aellen) and some varieties (see Aellen 1928, 1960-1961; Uotila, 1997, 2001a; Mosyakin, 2016; Mosyakin, Mandák, 2018, and references therein). Most probably several additional infraspecific entities or even segregate species will be recognized among Asian representatives of this group in the future.

In our opinion, $C$. ficifolium $\mathrm{s}$. 1. originated or at least diversified in southern and southeastern Asian regions, while in western Eurasia, including most of Europe, this species is an introduced archaeophyte (e.g., Preston et al., 2004). It is a more recent alien (kenophyte or neophyte; for terminology, see Richardson et al., 2011) in other parts of the world, as compared to Europe. In addition, at least some records of $C$. ficifolium worldwide are based on misidentifications, and thus the patterns of distribution and dispersal of that species in various parts of the world should be critically re-assessed based on reliable herbarium evidence.

\section{Chenopodium ficifolium in New Zealand: available historical evidence}

Sykes (1982) listed C. ficifolium as first reported from New Zealand by Kirk (1896). In that article Kirk reported his observations on "the introduction of injurious weeds in earth-ballast" of ships visiting the port of Wellington. Chenopodium ficifolium was initially revealed "in great abundance" (Kirk, 1896: 506) on a ballast heap at a railroad near the port; the following information was also provided: "Amongst the plants of the first year [1892 S.M. \& P.dL.] were Chenopodium ficifolium, Emex australis, Alternanthera sessilis, Galinsoga parviflora, Echium plantagineum, Cenia turbinata, Bowlesia tenera, Cichorium endivium, none of which made their appearance the second year [1893 - S.M. \& P.dL.] except the Chenopodium, which occurred in some quantity, and was represented by a few straggling specimens last year [1894 - S.M. \& P.dL.], although not a scrap is to be seen at this date [in 1895 - S.M. \& P.dL.]" (Kirk, 1896: 502). 
Cheeseman (1906: 1085) mentioned Kirk's specimen or specimens in Appendix II "List of plants naturalized in New Zealand", but not in the main part of his Manual of the New Zealand Flora. Subsequent reports of it from New Zealand were by Sykes (1982: 327) who noted C. ficifolium from "Wellington, Christchurch, Ashburton etc.", whilst Webb et al. (1988: 523) treated it as a $\zeta$ record (i.e., a failed or casual naturalization), noting that the species "has been collected in Wellington (in 1894) and occasionally elsewhere since". Thus, it looks like the apparent first appearance of $C$. ficifolium in New Zealand in the 1890s was as an ephemeral, and that to date this species is still regarded in New Zealand as an uncommon casual rather than fully naturalised species (Webb et al., 1988).

The question remains though, was Kirk's 1894 observation of Chenopodium ficifolium truly the first occurrence of this species in New Zealand? Considering the importance of shipping to the then fledgling New Zealand colony, and the virtual absence of any interest in biosecurity or indeed local expertise versed in recognising new incursions during the 1800 s, we think it highly likely that that there were possible earlier introductions of that species (as well as some other unnoticed alien taxa) within ship ballast, agricultural goods, or packaging material. Central to this problem is deciding on a date of a "first" introduction or naturalization, an issue that has been treated in differing ways by New Zealand botanists and flora writers. Clearly it is difficult to truly know the exact date of when a species has arrived. Realistically, when such dates are given, they more often than not reflect the first undisputed herbarium evidence of an introduction event, thus a putative "first record", rather than the actual "oldest" specimen. By way of example, the accepted "first record" supporting the naturalization of Banksia integrifolia L.f. (Proteaceae) to New Zealand was given as 1991 by Webb et al. (1995) despite the existence of specimens predating that record by four years (E.K. Cameron 1987, AK herbarium; here and below herbarium acronyms are given following Thiers, 2008-onward). While "first records" have a specific meaning to the authors concerned, to the general public the distinction is less clear, potentially causing problems when dealing with the incursion of exotic biota that pose a threat to New Zealand's indigenous biota, ecosystems, landscapes, and economy (see an overview in: Allen, Lee, 2006).

Below we explore this problem through the documentation of a herbarium specimen of Chenopodium ficifolium, most probably collected from northern New Zealand by J. Everard Home in the 1840s.
The specimen of Chenopodium ficifolium from New Zealand in the Turczaninow herbarium at KW

During a search for additional type specimens of Chenopodium s. 1. in the Turczaninow Historical Herbarium at the National Herbarium of Ukraine (KW, the herbarium of the M.G. Institute of Botany of the National Academy of Sciences of Ukraine), Sergei Mosyakin noticed in the general blue-paper folder labeled as "Chenopodium album" a specimen with the following label: "Chenopodium album L. | [one letter illegible, probably Greek $\gamma$ or $\varepsilon-$ S.M.] viride Moq. | Nova Zeelandia | Everard Home", KW barcode KW001003098, Fig. 1. The handwriting on the label corresponds to that on some other labels of Home's New Zealand specimens in the Turczaninow herbarium, e.g., the labels of original specimens of Geranium homeanum Turcz., KW001001014 and KW001001016 (see Mosyakin, de Lange, 2019). Most probably such labels are curatorial because their handwriting is different from that of J. Everard Home.

The original identification of the plant on the label of KW001003098 (C. album var. viride) needs some comments. This identification probably refers to the variety-rank name used by Moquin-Tandon in one of his publications. Moquin-Tandon (1840: 29) in his Chenopodearum monographica enumeratio used the name C. album L. $\gamma$ [var.] viridescens St.-Amans [sensu Moq.] with a synonym "Chenopodium viride plurimorum Auct. non Linn.", thus indicating that the name C. viride L. s. str. (which he then accepted in the sense now partly corresponding to C. opulifolium Schrad. ex Koch \& Ziz (1814); see Moquin-Tandon, 1840: 28) was misapplied by many authors ("plurimorum auctorum") to that variety. The reference to "St. Am." in MoquinTandon (1840: 29) refers to the book Flore Agenaise by J.F.B. de Saint-Amans (1821).

Saint-Amans (1821: 105) proposed the variety-rank epithet viridescens for $C$. viride L. s. str., as it is evident from his citation: " $\beta$. C. a. [Chenopodium album var.] viridescens. Grappes plus láches... C. viride. Linn. Sp. 319, exclus. Vaill. Syn... J.B. Hist. 2. p. 972". Since in the protologue of var. viridescens the name $C$. viride was cited in synonymy, the name $C$. album var. viridescens St.Amans is a superfluous name for the earlier combination C. album var. viride (L.) Pursh (Art. 52.1 of the ICN: Turland et al., 2018). In turn, Pursh (1813: 198) validated his variety $\beta$ viride (variety-rank combination in modern terms) through a direct reference to Willdenow (1798: 1303), where Linnaean $C$. viride was accepted as a species. 


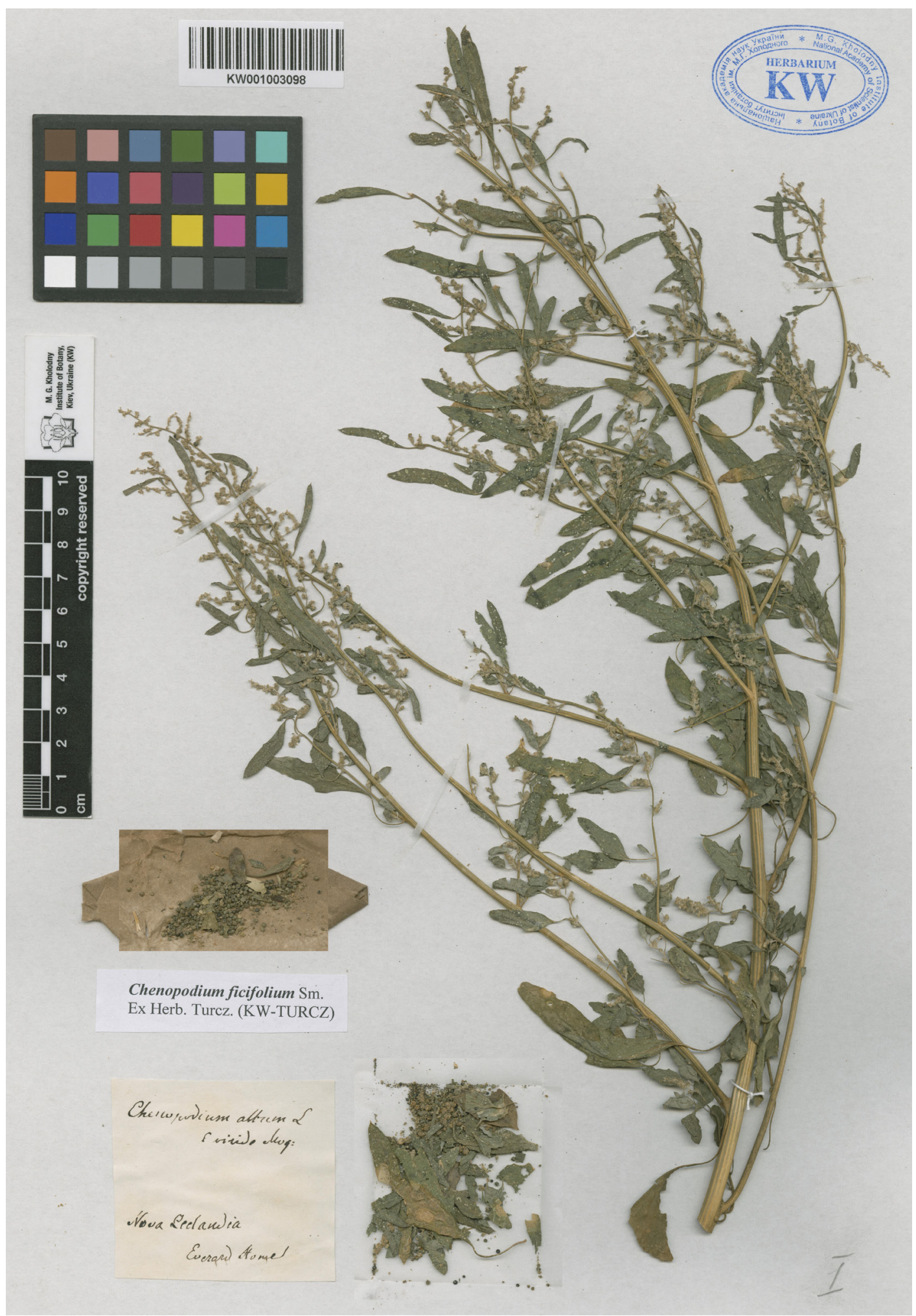

Figure 1. The specimen of Chenopodium ficifolium Sm. from the Turczaninow Historical Herbarium (KW-TURCZ) at the National Herbarium of Ukraine (KW): "Chenopodium album L. | [one letter illegible, probably Greek $\gamma$ or $\varepsilon$, meaning a variety] viride Moq. | Nova Zeelandia | Everard Home", KW barcode KW001003098 
For var. viridescens, Moquin-Tandon (1849: 71) applied in his treatment in de Candolle's Prodromus the same nomenclature and the same taxonomic concept as he did earlier (1840) in his Enumeratio..., but in 1849 he also accepted C. album $\varepsilon$ [var.] viride based on $C$. viride L. s. str. The treatment in Prodromus was probably the source of identification of the New Zealand plant in the Turczaninow herbarium.

Now the name $C$. viride $\mathrm{L}$. has been proposed for rejection (Mosyakin, Iamonico, 2018) because of the uncertain identity of its type and also because that name was widely and inconsistently misapplied by many authors to several related or even quite unrelated taxa of Chenopodium, including species now accepted as C. ficifolium, C. opulifolium, C. suecicum, etc.

\section{Reconstructing a possible history of Home's specimen of Chenopodium ficifolium}

The British naval officer Sir James Everard Home (1798-1853) was also a plant collector who contributed to British herbaria with his specimens from China and Australasia (Beasley, 2000; Godley, 2010; JSTOR Global Plants, 2013-onward). Plant collections of or separate specimens collected by J. Everard Home are known to be deposited in the following herbaria: BM, K, LINNSM, and FI (Jackson, 1901; Murray, 1904; Lanjouw, Stafleu, 1957; JSTOR Global Plants, 2013-onward). Until recently, no published information was available on the presence of Home's specimens in KW, but now we understand that many of his important specimens, mainly those from New Zealand, are incorporated in the vast Turczaninow historical herbarium (see Marchant, 1990; Mosyakin et al., 2019; Mosyakin, de Lange, 2019, and references therein).

Captain Home was given command of the frigate HMS North Star in 1841 and served on that ship until 1846. During this period, he in 1841-1842 participated in military operations (the First Anglo-Chinese War, also known as the Opium War) and did some scientific observations in China, visited and was stationed in Australia, and also visited New Zealand four times, in $1843,1845,1845-1846$, and then briefly in 1852 (Godley, 2010; JSTOR Global Plants, 2013-onward). It is thought that most of his botanical collections from New Zealand were made during the second and third visits there, so probably the specimen of C. ficifolium (KW001001014) was collected in the mid-1840s.

Jackson (1901: 33) reported that Home's collections from Australia and New Zealand were received by the Kew Gardens in 1846-1851. He, however, noted in the introductory part of his list that "there is no detailed records of the plants exchanged or presented to other herbaria, so that, though the collections here named were once here [at Kew] they may have since been transferred to other possessors" (Jackson, 1901: 2). That was probably what happened to some of the Kew collections of Everard Home, which were exchanged for some of Turczaninow's specimens. Jackson (1901: 65) listed "Turczaninow, Nicolas Stepanowitch, Baical, 1833-42" [the reported years cover most of the Siberian period (1828-1844) in the life of Turczaninow], thus indicating that the $\mathrm{K}$ herbarium received duplicates of Turczaninow's Siberian plants, which were used by the author for compiling his Flora Baicalensi-Dahurica; for bibliography and other details on that Flora, see Stafleu (1969), Lipschitz (1964), and Stafleu \& Cowan (1986).

Murray (1904: 87 156) reported that the Department of Botany of the British Museum received in 1843 "90 plants from the east coast of China collected and presented by Sir Everard Home; the following year, 51 plants were presented" (Murray 1904: 87). In 1846 the Museum received "715 plants from Australia and the Pacific Islands, collected and presented by Sir Everard Home; in 1853, 400 plants, with numerous cryptogams, were presented; in 1854, 174" (Murray, 1904: 88). This information is also summarized on p. 156, where Murray (l.c.) reports 141 plant specimens from China presented in $1843-1844$, and totally 1286 specimens from Australia and the Pacific presented in 1846 and 1853. It should be noted that in that case Murray (l.c.) reported the donations of Captain Sir J. Everard Home ( $2^{\text {nd }}$ Baronet), not to be confused with his father Sir Everard Home (1756-1832; see Beasley, 1997, 2000), a British surgeon who was also mentioned (as "Sir Everard Home, Bart. [Baronet]") in the same volume as the presenter of a paleontological specimen, the "part of the vertebral column of Ichthyosaurus, from Lower Lias, Lyme Regis" (see Woodward 1904: 202, 298).

The visits of British ships to the Australasian region (Australia and/or New Zealand) and various southern and eastern regions of Asia (China, India, etc.) during the same navigation were definitely not exceptional. The ships often stopped in various East Indian and Chinese ports for supplies or trade items on the way to and from Australia and/or New Zealand. Early introductions of various weedy species brought to New Zealand in the $19^{\text {th }}$ century with agricultural / horticultural goods and supplies or ship ballast are documented in many publications (see Allan, 1940; Williams, Cameron, 2006, and references therein). 
Since C. ficifolium is one of the common species of Chenopodium in these parts of Asia (or the most common Chenopodium in some regions, judging from the experience of Sergei Mosyakin at various herbaria containing SE Asian specimens), there is little surprise that the seeds of that weedy species were probably brought to New Zealand quite early, in the first half of the $19^{\text {th }}$ century, as contaminants of grain or other agricultural goods, or with ship ballast. Alternatively, the diaspores of C. ficifolium may have been brought from Europe, in particular, Britain, where that species was definitely present at that time (Preston et al., 2004). Judging from the characters of the KW specimen collected by Home, the plant belongs to C. ficifolium subsp. ficifolium, not to the Asian subsp. blomianum. However, subsp. ficifolium is also rather widespread in eastern Asia (see, e.g., comments in Dostálek, 1986) and the particular morphotype represented by the specimen KW001003098 is known from both Asia and Europe. Thus, the direct source of immigration in that case remains elusive.

One may argue that, since Home collected both in China and New Zealand, his specimen of C. ficifolium may have in fact originated in China but was mislabelled as a plant collected in New Zealand. Indeed, a chance of mislabelling always exists for any old herbarium, and such occasional cases are known in the Turczaninow herbarium as well, a few of them applicable to taxa supposedly described from New Zealand (see comments in Gardner, 2020). However, in our opinion, in the particular case of $C$. ficifolium this chance is almost negligible and definitely not higher than that with any other average specimen from the Turczaninow collection. The specimen of $C$. ficifolium and its label look naturally as if they belong to each other and, judging from impressions that were on the original blue-paper folder containing the specimen, neither the plant nor the label were misplaced since the times when Turczaninow placed them there. The realistic possibility of an event of early introduction of that species to New Zealand, either from its native range in Asia or from its secondary range in Europe, is discussed and evaluated above.

\section{Chenopodium ficifolium in New Zealand: the present status}

In the interim Chenopodium ficifolium remains an uncommon plant in New Zealand. In that country it is known from at least seven collections lodged in the three main herbaria of New Zealand, AK, CHR, and WELT. On this evidence, the species is still a casual in that country's naturalized flora. However, despite the few collections available, it seems to be rather widespread (even if scattered), with collections, including the Home specimen discussed above, ranging from the North Island (where it has been collected from Auckland and Wellington) to the South Island (Christchurch), with one collection from Poutama Island, one of the southern Titi Islands located south-west of Rakiura / Stewart Island. One recent iNaturalist observation (https://www.inaturalist. org/observations/36525112; also available from GBIF: https://www.gbif.org/occurrence/2579254739) made on 9 December 2019 in Christchurch shows three photographs of plants unmistakably identifiable as C. ficifolium s. str. The species is probably more widespread than this, as it has been widely confused with C. album, an extremely common and widely distributed naturalized species found throughout New Zealand, including the Chatham Islands (Webb et al., 1988; de Lange et al., 2011).

Judging from its present-day "ecological behavior" in Europe (see, for example, Preston et al., 2004; Thomas, Palmer, 2015, electronic supplement; Nobis et al., 2018, etc.), C. ficifolium has a rather low invasive potential and its chances to become a noxious invasive weed in New Zealand are rather low. However, other studies list C. ficifolium among "weeds that are increasingly spreading in Europe", especially weeds of grain legumes and root crops (Weber, Gut, 2005). The personal experience of the first author (Sergei Mosyakin) in Ukraine indicates that in that respect $C$. ficifolium is a rather unpredictable "oscillating" species, which sometimes can appear locally in great abundance (especially in crop fields or in gardens), but in just a few years can disappear totally or almost totally from that particular locality. Thus, New Zealand botanists, ecologists and farmers should keep a watchful eye on that seemingly innocent (not yet invasive) alien species.

\section{Concluding remarks}

The case described in the present note emphasizes the importance of old historical herbarium collections for tracing the dispersal and immigration patterns of alien species across the globe. A special revision of the 19-century herbarium specimens of Chenopodium (especially those identified as $C$. album, $C$. viride, etc.) from New Zealand is needed to confirm that $C$. ficifolium was indeed first brought to New Zealand and occurred there almost 50 years before it previously known "first official" record by Kirk (1896), or if additional collections were made between the mid-1840s and the 1890s.

We expect that a thorough revision of New Zealand specimens of early collectors and explorers, such as J. Everard Home, Allan and Richard Cunningham, which were recently revealed in the Turczaninow historical 
herbarium at $\mathrm{KW}$, may bring important and interesting results not only on native plants (including type specimens), but also for non-native species introduced during the early stages of the European colonization, which will document their earliest stages of expansion.

\section{Acknowledgments}

We are grateful to Natalia M. Shiyan, Alisa V. Shumilova, and Svitlana I. Antonenko (M.G. Kholodny Institute of Botany, National Academy of Sciences of Ukraine, Kyiv, Ukraine) for providing their assistance during the herbarium research of Sergei Mosyakin at KW. We also thank the staff and curators of AK (Ewen Cameron, Yumiko Baba), CHR (Ines Schönberger, Kate Boardman), and WELT (Leon Perrie) for their assistance with locating New Zealand specimens of Chenopodium ficifolium.

\section{References}

Aellen P. 1928. Neue adventiv Chenopodium aus Schweden. Botaniska Notiser (Lund) [vol. of 1928]: 203-210.

Aellen P. 1929. Chenopodium ficifolium Sm. und seine Verwandten der eurasischen Flora. Repertorium Specierum Novarum Regni Vegetabilis, 27: 220-223.

Aellen P. 1941. Zur Nomenklatur und Kenntnis von Chenopodium ficifolium Smith resp. serotinum L. und Chenopodium viride L. Verhandlungen der Naturforschenden Gesellschaft in Basel, 52: 158-159.

Aellen P. 1960-1961. Chenopodiaceae. In: Hegi G. Illustrierte Flora von Mitteleuropa, Aufl. 2 ( $2^{\text {nd }}$ ed.), Bd. (vol.) 3, T. (part) 2, Lief. 2-4. München: Lehmann Verlag [Reprinted in 1979: Berlin \& Hamburg: Paul Parey Verlag], pp. 533-762.

Allan H.H. 1940. A handbook of the naturalized flora of New Zealand. [New Zealand DSIR (Department of Scientific and Industrial Research) Bulletin 83]. Wellington, New Zealand: Government Printer, 344 pp.

Allan H.H. 1961. Flora of New Zealand, vol. 1. Wellington, New Zealand: P.D. Hasselberg, Government Printer, liv + $1083 \mathrm{pp}$

Allen R.B., Lee W.G. (eds.). 2006. Biological invasions in New Zealand. [Ecological Studies, vol. 186]. Berlin; Heidelberg; New York: Springer Verlag, xxiv +457 pp. https://doi.org/10.1007/3-540-30023-6

Beasley A.W. 1997. Home away from home. Australian and New Zealand Journal of Surgery, 67: 547-550. https://doi. org/10.1111/j.1445-2197.1997.tb02035.x

Beasley A.W. 2000. Home away from home. Wellington, N.Z.: Central Institute of Technology, in association with Grantham House, 158 pp.

Cheeseman T.F. 1906. Manual of the New Zealand flora. Wellington: Government Printer, xxxvi + 1199 pp. https:// doi.org/10.5962/bhl.title. 12003
Clemants S.E. 2006. Chenopodiaceae. In: Iwatsuki K., Boufford D.E., Ohba H. (eds.). Flora of Japan, vol. 2a. Tokyo: Kodansha, pp. 212-221.

Clemants S.E., Mosyakin S.L. 2003. Chenopodium. In: Flora of North America Editorial Committee (Eds.). Flora of North America North of Mexico, vol. 4. New York \& Oxford: Oxford University Press, pp. 275-299.

de Lange P.J., Heenan P.B., Rolfe J.R. 2011. Checklist of vascular plants recorded from the Chatham Islands. Wellington: Department of Conservation, 57 pp. Available at: https:/www.doc.govt.nz/globalassets/documents/ conservation/native-plants/chatham-islands-vascularplants-checklist.pdf

Dostálek J. 1986. Chenopodium ficifolium Smith in the North Korea (D.P.R.K.). Preslia 58: 273-275.

Feodorova T.A. 2014. Chenopodium, Blitum, Dysphania. In: Maevskiy P.F. Flora of the middle zone of the European part of Russia. $11^{\text {th }}$ ed. Moscow: KMK Scientific Press, pp. 91-94. [Федорова Т.А. 2014. Chenopodium, Blitum, Dysphania. В кн.: Маевский П.Ф. Флора средней полосы европейской части России. 11-е изд. Москва: Товарищество научных изданий КМК, с. 91-94].

Feodorova T.A. 2018. Blitum, Chenopodium, Dysphania. In: Reshetnikova N.M. (ed.). Flora of the Lower Volga area, vol. 2, part 1. Moscow: KMK Scientific Press, pp. 118132. [Федорова T.A. 2018. Blitum, Chenopodium, Dysphania. В кн.: Флора Нижнего Поволжья, т. 2, часть 1. Отв. ред. Н.М. Решетникова. Москва: Товарищество научных изданий КМК, с. 118-132].

Fuentes-Bazan S., Mansion G., Borsch T. 2012a. Towards a species level tree of the globally diverse genus Chenopodium (Chenopodiaceae). Molecular Phylogenetics and Evolution 62: 359-374. https://doi. org/10.1016/j.ympev.2011.10.006

Fuentes-Bazan S., Uotila P., Borsch T. 2012b. A novel phylogeny-based generic classification for Chenopodium sensu lato, and a tribal rearrangement of Chenopodioideae (Chenopodiaceae). Willdenowia, 42: 5-24. https://doi. org/10.3372/wi.42.42101

Gardner R. 2020. Plants from "New Zealand" named by N.S. Turczaninov, and a note on collector W. Stephenson. New Zealand Botanical Society Newsletter, 139: 10-13.

Godley E.J. 2010. Biographical Notes (76). Captain Sir James Everard Home (1798-1853). New Zealand Botanical Society Newsletter, 100: 16-19.

Hernández-Ledesma P., Berendsohn W.G., Borsch T., von Mering S., Akhani H., Arias S., Castañeda-Noa I., Eggli U., Eriksson R., Flores-Olvera H., Fuentes-Bazán S., Kadereit G., Klak C., Korotkova N., Nyffeler R., Ocampo G., Ochoterena H., Oxelman B., Rabeler R.K., Sanchez A., Schlumpberger B.O., Uotila P. 2015. A taxonomic backbone for the global synthesis of species diversity in the angiosperm order Caryophyllales. Willdenowia, 45: 281-383. http://dx.doi.org/10.3372/wi.45.45301

Jackson W.T.T. 1901. A list of the collectors whose plants are in the herbarium of the Royal Botanic Gardens, Kew, to $31^{\text {st }}$ December, 1899. Bulletin of Miscellaneous Information (Royal Botanic Gardens, Kew), Nos. 169-171: 1-80. 
JSTOR Global Plants. 2013-onward. Home, James Everard (1798-1853). Available at: https://plants.jstor.org/ stable/10.5555/al.ap.person.bm000393164 (Accessed 20 February 2020).

Kirk T. 1896. On the products of a ballast-heap. Transactions and Proceedings of the New Zealand Institute, 28 [vol. of 1895]: 501-507.

Koch W.D.J., Ziz J.B. 1814. Catalogus plantarum, quas in ditione Florae Palatinatus legerunt G. Koch et J.B. Ziz, in amicorum usum conscriptas. Phanerogamia. Moguntiae [Mainz], 24 pp.

Lanjouw J., Stafleu F.A. 1957. Index Herbariorum, Part II(2): Collectors E-H. [Regnum vegetabile, vol. 9]. Utrecht: International Bureau of Plant Taxonomy and Nomenclature of the International Association for Plant Taxonomy, pp. 175-295.

Lipschitz S.Yu. 1964. Life and works of the outstanding Russian botanist and plant taxonomist N.S. Turczaninow (1796-1863). A report delivered at the General Session of the All-Union Botanical Society on 18 December 1963. Botanicheskii Zhurnal, 49(5): 752-766. [Липшиц С.Ю. 1964. Жизнь и творчество замечательного русского ботаника-систематика Н.С. Турчанинова (1796-1863). Доклад, прочитанный на общем собрании Всесоюзного Ботанического общества 18.XII.1963 г. Ботанический журнал, 49(5): 752-766].

Mandák B., Krak K., Vít P., Lomonosova M.N., Belyayev A., Habibi F., Wang L., Douda J., Štorchová H. 2018. Hybridization and polyploidization within the Chenopodium album aggregate analysed by means of cytological and molecular markers. Molecular Phylogenetics and Evolution, 129: 189-201. https://oi. org/10.1016/j.ympev.2018.08.016

Marchant N.G. 1990. The contribution of the Russian botanist Turczaninov to Australian plant taxonomy. In: History of Systematic Botany in Australasia. Proceedings of a symposium held at the University of Melbourne 25-27 May 1988. Ed. P.S. Short. Canberra: ASBS, pp. 121-130.

Moquin-Tandon A. 1840. Chenopodearum monographica enumeratio. Parisiis [Paris]: Apud P.-J. Loss, ix + 182 pp. https://doi.org/10.5962/bhl.title.15484

Moquin-Tandon A. 1849. Ordo Salsolaceae. In: de Candolle A.P. (ed.). Prodromus Systematis Naturalis Regni Vegetabilis, vol. 13(2). Parisiis [Paris]: Apud P.-J. Loss, pp. 41-219.

Mosyakin S.L. 2016. First record of Chenopodium ficifolium subsp. blomianum (Chenopodiaceae) in North America. Phytoneuron, 2016-33: 1-6. Available at: http:// www.phytoneuron.net/2016Phytoneuron/33PhytoNChenopodiumblomianum.pdf

Mosyakin S.L., Clemants S.E. 2002. New nomenclatural combinations in Dysphania R.Br. (Chenopodiaceae): taxa occurring in North America. Ukrainian Botanical Journal, 59(4): 380-385.

Mosyakin S.L., Clemants S.E. 2008. Further transfers of glandular-pubescent species from Chenopodium subg. Ambrosia to Dysphania (Chenopodiaceae). Journal of the Botanical Research Institute of Texas, 2(1): 425-431. Available at: https://www.jstor.org/stable/41971654

Mosyakin S.L., de Lange P.J. 2019. Notes on typification and nomenclature of four taxa of Geraniaceae described by Turczaninow from New Zealand and Australia. Phytotaxa, 419(2): 169-181. http://dx.doi.org/10.11646/ phytotaxa.419.2.3

Mosyakin S.L., Iamonico D. 2018. (2632) Proposal to reject the name Chenopodium viride (Chenopodiaceae; Amaranthaceae sensu APG). Taxon, 67(4): 811-812. https://doi.org/10.12705/674.17

Mosyakin S.L., Mandák B. 2018. (2658) Proposal to reject the name Atriplex bengalensis (Chenopodium bengalense) (Chenopodiaceae / Amaranthaceae sensu APG). Taxon, 67(6): 1218-1219. https://doi.org/10.12705/676.27

Mosyakin S.L., McNeill J., Boiko G.V. 2019. Comments on proper type designation for names of taxa validated by Turczaninow in his Animadversiones, with case studies. Ukrainian Botanical Journal, 76(5): 379-389. https://doi. org/10.15407/ukrbotj76.05.379

Murray G. 1904. The Department of Botany. In: The history of the collections contained in the Natural History departments of the British Museum, vol. 1. London: Printed by order of the Trustees of the British Museum, by William Clowes and Sons, Limited, pp. 79-193. https:// doi.org/10.5962/bhl.title.20926

Nobis A., Nowak A., Rola K. 2018. Do invasive alien plants really threaten river bank vegetation? A case study based on plant communities typical for Chenopodium ficifolium an indicator of large river valleys. PLoS ONE, 13(3): e0194473. https://doi.org/10.1371/journal.pone.0194473

Paul T.K. 2012. A synopsis of the family Chenopodiaceae in India. Pleione, 6(2): 273-297.

POWO. 2020-onward. Plants of the World Online. Facilitated by the Royal Botanic Gardens, Kew. Available at: http:// www.plantsoftheworldonline.org (Accessed 20 February and 18 March 2020).

Preston C.D., Pearman D.A., Hall A.R. 2004. Archaeophytes in Britain. Botanical Journal of the Linnean Society, 145(3): 257-294. https://doi. org/10.1111/j.1095-8339.2004.00284.x

Pursh F. 1813 [dated as 1814]. Flora Americae Septentrionalis; or, a Systematic arrangement and description of the plants of North America. Containing, besides what have been described by preceding authors, many new and rare species, collected during twelve years travels and residence in that country, vol. 1. London: Printed for White, Cochrane, and Co., by Richard and Arthur Taylor, xxxvi +358 pp.

Richardson D.M., Pyšek P., Carlton J.T. 2011. A compendium of essential concepts and terminology in biological invasions. In: Richardson D.M. (ed.). Fifty years of invasion ecology: the legacy of Charles Elton. Oxford: Blackwell Publishing, pp. 409-420.

Saint-Amans J.F.B de. 1821. Flore Agenaise; ou, Description méthodique des plantes observées dans le département de Lot-et-Garonne et dans quelques parties des départemens voisins. Agen: Prosper Noubel, $61+632$ pp. 
Stafleu F.A. 1969. Turczaninow's Flora Baicalensi-Dahurica. Taxon, 8(5): 563-565. Available at: https://www.jstor.org/ stable/1218386

Stafleu F.A., Cowan R.S. 1986. Taxonomic literature: A selective guide to botanical publications and collections with dates, commentaries and types, vol. 6: Sti-Vuy. $2^{\text {nd }}$ ed. Utrecht; Antwerpen: Bohn, Scheltema \& Holkema / The Hague; Boston: dr. W. Junk b.v., Publishers, 926 pp.

Sukhorukov A.P., Kushunina M.A., Verloove F. 2016a. Notes on Atriplex, Oxybasis and Dysphania (Chenopodiaceae) in West-Central Tropical Africa. Plant Ecology and Evolution 149(2): 249-256. https://doi.org/10.5091/ plecevo.2016.1181

Sukhorukov A.P., Aellen P., Edmondson J.R., Townsend C.C. 2016b. Chenopodiaceae. In: Ghazanfar S.A., Edmondson J.R. (eds.). Flora of Iraq, vol. 5(1). Glasgow: Bell and Bain Ltd, pp. 164-256.

Sukhorukov A.P., Liu P.-L., Kushunina M. 2019. Taxonomic revision of Chenopodiaceae in Himalaya and Tibet. PhytoKeys, 116: 1-141. https://doi.org/10.3897/ phytokeys.116.27301

Sykes W.R. 1982. Checklist of dicotyledons naturalised in New Zealand 14. Chenopodiales and Polygonales. New Zealand Journal of Botany, 20(4): 325-331. https://doi.or $\mathrm{g} / 10.1080 / 0028825 X .1982 .10428501$

Thiers B. 2008-onward. Index Herbariorum. A global directory of public herbaria and associated staff. New York Botanical Garden's Virtual Herbarium. Available at: http://sweetgum.nybg.org/science/ih (Accessed 18 March 2020).

Thomas C.D., Palmer G. 2015. Non-native plants add to the British flora without negative consequences for native diversity. Proceedings of the National Academy of Sciences [USA], 112(14): 4387-4392. Available at: www.pnas.org/ cgi/doi/10.1073/pnas.1423995112

Turland N.J., Wiersema J.H., Barrie F.R., Greuter W., Hawksworth D.L., Herendeen P.S., Knapp S., Kusber W.-H., Li D.-Z., Marhold K., May T.W., McNeill J., Monro A.M., Prado J., Price M.J., Smith G.F. 2018. International Code of Nomenclature for algae, fungi, and plants (Shenzhen Code) adopted by the Nineteenth International Botanical Congress, Shenzhen, China, July 2017. Glashütten: Koeltz Botanical Books. Regnum Vegetabile, 159: i-xxxviii + 1-254. https://doi.org/10.12705/Code. 2018

Uotila P. 1979. Atriplex prostrata subsp. polonica and Chenopodium serotinum. Annales Botanici Fennici, 16: 197-198.

Uotila P. 1997. Chenopodium. In: Rechinger K.-H. (ed.). Flora Iranica, No. 172, Chenopodiaceae. Graz: Akademische Druck- u. Verlagsanstalt, pp. 24-59.

Uotila P. 2001a. Chenopodium. In: Ali S.I., Qaiser M. (eds.). Flora of Pakistan, No. 204. Karachi: Dept. of Botany, Univ. of Karachi \& St. Louis: Missouri Botanical [Garden] Press, Missouri Botanical Garden, pp. 13-52.
Uotila P. 2001b. Chenopodium. In: Jonsell B. (ed.). Flora Nordica, vol. 2. Stockholm: Bergius Foundation, Royal Swedish Academy of Sciences, pp. 4-31.

Walsh B.M., Adhikary D., Maughan P.J., Emshwiller E., Jellen E.N. 2015. Chenopodium polyploidy inferences from Salt Overly Sensitive 1 (SOS1) data. American Journal of Botany, 102(4): 533-543. https://doi. org/10.3732/ajb.1400344

Webb C.J., Sykes W.R., Garnock-Jones P.J. 1988. Flora of New Zealand, vol. 4. Christchurch: Botany Division, Department of Scientific and Industrial Research (DSIR), lxviii +1365 pp.

Webb C.J., Sykes W.R., Garnock-Jones P.J., Brownsey P.J. 1995. Checklist of dicotyledons, gymnosperms, and pteridophytes naturalised or casual in New Zealand: additional records 1988-1993. New Zealand Journal of Botany, 33: 151-182.

Weber E., Gut D. 2005. A survey of weeds that are increasingly spreading in Europe. Agronomy for Sustainable Development, 25(1): 109-121. https://doi.org/10.1051/ agro:2004061

Williams P.A., Cameron E.K. 2006. Creating Gardens: The diversity and progression of European plant introductions. In: Allen R.B., Lee W.G. (eds.). Biological invasions in New Zealand. [Ecological Studies, vol. 186]. Berlin; Heidelberg; New York: Springer Verlag, pp. 33-47. https:// doi.org/10.1007/3-540-30023-6_3

Wilson P.G. 1984. Chenopodiaceae. In: George A.S. (ed.). Flora of Australia, vol. 4. Canberra: Australian Government Publishing Service, pp. 81-317.

Willdenow C.L. 1798. Caroli a Linné Species Plantarum: exhibentes plantas rite cognitas, ad genera relatas, cum differentiis specificis, nominibus trivialibus, synonymis selectis, locis natalibus, secundum systema sexuale digestas, $4^{\text {th }}$ ed., vol. 1(2). Berolini [Berlin]: G.C. Nauk, pp. 499-1568. https://doi.org/10.5962/bhl.title.727

Woodward A.S. 1904. The Department of Geology. In: The history of the collections contained in the Natural History departments of the British Museum, vol. 1. London: Printed by order of the Trustees of the British Museum, by William Clowes and Sons, Limited, 1904, pp. 195-340. https://doi.org/10.5962/bhl.title.20926

Zhu G.-L., Sanderson S.C. 2017. Genera and a new evolutionary system of World Chenopodiaceae. Beijing: Science Press, $361 \mathrm{pp}$.

Zhu G., Zhang M. 2016. Resurrection of the genus Botrydium Spach (Chenopodiaceae), with a description of four new species from China, Peru and Burundi. Plant Diversity, 38(6): 322-329. https://doi.org/10.1016/j.pld.2016.10.005

Zhu G.-L., Mosyakin S.L., Clemants S.E. 2003. Chenopodiaceae. In: Wu Z.-Y., Raven P.H., Hong D.-Y. (eds.). Flora of China, vol. 5. Beijing: Science Press \& St. Louis: Missouri Botanical Garden Press, pp. 351-414.

Recommended for publication by D.V. Dubyna 